Krzysztof Sychowicz

Oddziat IPN w Biatymstoku

Państwowa Wyższa Szkota Informatyki i Przedsiębiorczości w Łomży

\title{
Działania władz komunistycznych wobec Wyższego Seminarium Duchownego w Białymstoku na przełomie lat pięćdziesiątych i sześćdziesiątych XX wieku
}

\section{COMMUNIST AUTHORITIES ACTIONS TOWARDS THE SEMINARY IN BIAŁYSTOK AT THE TURN OF 50S AND 60S OF XX CENTURY}

Since the moment of coming into being the Seminary in Białystok was in the sphere of interest the omnipresent secret police after the Second World War. According to the secret police, it was negative to familiarize seminarians with structures of teenager organizations, namely with the Scouts; the meetings of ex-scouts and the symphatizers of the organization which took place in Białystok were not positive, either .The statements and seminarians' attitudes towards the Seminary in Białystok aroused the interest of the secret police. At the turn of $50 \mathrm{~s}$ and 60 s there was a period of official 'political thaw' nevertheless, it was a period of priests which -hunt and an attempt of taking supervision over seminaries by authorities. In province Białystok the situation in the Seminaries was analyzed by the secret police, emphasising the low recruitment standards which were caused by the seminarians military conscription.

The official actions of administrative authorities met with bishop Władysław Suszyński resistance which was gradually breaking down. The restrictions on his activity were being developed in the next years, as an example of restrictions could be a telegram sent by the Religious Office in Warsaw to Religious Departament of the National Council Presidium in Białystok on 29th June, 1965. It was indicated in the message that there were possibilities of negative 
consequences in relation to the Seminary in Białystok because of the Seminaries' definitely negative attitude towards authorities and law regulations.

Key words: Roman Catholic Church, Seminary in Białystok, secret police, Religious Department, Province Committee of Civic Police, Province National Council.

Historia Kościoła

4 kwietnia 1945 roku Kolegium Specjalne NKWD ZSRR podjęło ostatecznie decyzję o wydaleniu abp. Romualda Jałbrzykowskiego do Polski, co nastąpiło 14 lipca tego roku. Po przybyciu na Białostocczyznę od samego początku został on otoczony „opieką” przez komunistów ${ }^{1}$. W bardzo trudnych warunkach, w kilku pokojach odstąpionych przez dziekana Aleksandra Chodyko, arcybiskup zaczął trwający kilka lat proces tworzenia urzędów kościelnych ${ }^{2}$. Między innymi 29 marca 1945 roku podpisano umowę przekazującą jeden budynek przy ul. Słonimskiej 8 na rzecz repatriowanego z terytorium Litewskiej Socjalistycznej Republiki Radzieckiej seminarium ${ }^{3}$ rzymskokatolickiego (przed wojną należał do Braci Sług Najświętszej Maryi Panny i św. Franciszka). Najem został zawarty na piętnaście lat ${ }^{4}$.

Nie oznaczało to pozostawienia seminarium bez nadzoru przedstawicieli władz i instytucji tworzonych przez system komunistyczny. Chociaż tworzony od sierpnia 1944 roku Wojewódzki Urząd Bezpieczeństwa Publicznego w Białymstoku i powstałe później Powiatowe Urzędy Bezpieczeństwa Publicznego początkowo mniej uwagi poświęcały Kościołowi katolickiemu, to już 23 stycznia 1946 roku pracownicy Sekcji V prowadzili m.in. sprawy obiektowe o kryptonimach: „Biały” na kościół św. Rocha, „Fary” na kościół katedralny, „Wojciech” na kościól św. Wojciecha i „Duch” na Seminarium Duchowne ${ }^{5}$. Elementem dodatkowo zaogniającym sytuację i istniejący na Białostocczyźnie

$1 \quad$ A. Szot, Abp Romuald Jatbrzykowski metropolita wileński, Lublin 2002, s. 280 in.

Ibidem, s. $282 \mathrm{in.}$

3 O okolicznościach jego tworzenia zob. T. Krahel, Seminarium duchowne w Biatymstoku w minionym50-leciu, „Wiadomości Kościelne Archidiecezji Białostockiej” 1995, nr 4(99), s. 140-149.

4 APB, KW PZPR w Białymstoku, 643, Umowa najmu zawarta pomiędzy Jerzym Kockim a ks. Janem Krassowskim przedstawicielem Seminarium Duchownego, 29 III 1945 r., k. 213 i nast.; T. Krahel, Dzieje Archidiecezjalnego Wyższego Seminarium Duchownego w Biatymstoku [w:] Archidiecezjalne Wyższe Seminarium Duchowne w Białymstoku 1945-1980, opr. E. Ozorowski, Białystok 1981, s. 15.

AIPN Bi, 045/1093, Sprawozdanie z pracy agenturalno-operacyjnej Wydziału V WUBP w Białymstoku za okres 12-20 I 1946 r., k. 4; ibidem, Sprawozdanie 
konflikt pomiędzy władzami komunistycznymi a Kościołem katolickim stała się konsekracja na biskupa rektora Seminarium Duchownego ks. Ignacego Świrskiego, która została przesunięta w ostatniej chwili na 30 czerwca 1946 roku (data referendum ludowego). Odbyła się ona pomimo interwencji KC PPR i wojewody białostockiego, gromadząc w kościele i na cmentarzu kościelnym rzesze wiernych. Przybył w tym dniu nawet prymas August Hlond, w związku z czym w godz. 8.3013.15 frekwencja w głosowaniu była zmniejszona do minimum ${ }^{6}$. Rok Historia później zainteresowano się profesorem Seminarium Duchownego w Białymstoku ks. Aleksandrem Mościckim, który według informacji uzyskanych przez aparat bezpieczeństwa miał być wyświęcony na biskupa i przeniesiony do Siedlec jako sufragan?

Natomiast w kwietniu 1948 roku aparat bezpieczeństwa uzyskał informacje, że w Seminarium Duchownym do programu nauk wstawiono zaznajamianie alumnów z życiem organizacji młodzieżowych, w tym harcerstwa. Na jego terenie odbywały się nawet luźne zebrania alumnów byłych harcerzy i sympatyków tej organizacji. Ksiądz Aleksander Mościcki oświadczył ponadto alumnom, że te informacje będą im potrzebne w przyszłości w pracy z organizacjami młodzieżowymi. Zeznał o tym alumn I roku, były członek WiN Adam Niewiarowski, u którego znaleziono podczas rewizji osobistej notatnik harcerski drużyny im. Arciszewskiego. Zawierał on zapisy, iż Prezydentem RP jest Władysław Raczkiewicz, a wodzem naczelnym Bór Komorowski ${ }^{8}$. Wszystko to potwierdzało niechętny stosunek nie tylko profesorów seminarium, ale i całej Kurii wobec systemu komunistycznego.

Nasilenie represji wobec duchowieństwa katolickiego i pozostających jeszcze pod jego kontrolą organizacji nastąpiło na przełomie lat czterdziestych i pięćdziesiątych Kuria w Białymstoku w 1953 roku swoim zasięgiem obejmowała dwa powiaty: sokólski i białostocki, posiadała sześć dekanatów z 59 parafiami, 152 księży, jedno seminarium ze 100 alumnami, małe seminarium duchowne z 305 uczniami, jeden zakon

z pracy agenturalno-operacyjnej Wydziału V WUBP w Białymstoku za okres 20 I-1 II 1946 r., k. 11.

$6 \quad$ AIPN Bi, 045/1096, Sprawozdanie Wydziału V WUBP w Białymstoku do dyrektora Departamentu V MBP w Warszawie z akcji głosowania ludowego w 1946 r., k. 37, 48; AIPN Bi, 045/1101, Sprawozdanie z pracy agenturalno-informatorskiej Sekcji V Wydziału V WUBP w Białymstoku za okres 10-20 VII 1946, k. 63.

$7 \quad$ AIPN Bi, 045/1102, Raport okresowy naczelnika Wydziału V za okres 15-31 XII 1947 r., k. 140; Ibidem, Raport okresowy naczelnika Wydziału V za okres 1-15 XII 1947 r., k. 135.

$8 \quad$ Ibidem, 045/1108, Raport okresowy naczelnika Wydziału V WUBP za okres od 1 IV 1948 r. do 30 IV 1948 r., k. 30. 
męski z 29 zakonnikami, 10 domów zakonnych żeńskich z 131 zakonnicami. Do tej pory była nieuznawana przez władze, w związku z czym wnioskowano o utrzymanie tego stanu oraz zlikwidowanie administracji kurialnej i przyłączenie parafii do Kurii łomżyńskiej ${ }^{9} 23$ stycznia 1954 roku na potrzeby KW PZPR w Białymstoku sporządzono analizę mających miejsce rok wcześniej działań wobec duchowieństwa, w której odnotowano też fakt obrony przez księży sądzonego we wrześniu 1953 roku biskupa kieleckiego Czesława Kaczmarka. Twierdzili oni, co z oburzeniem zanotowano, że rząd prowadził walkę z Kościołem. Ksiądz Witold Pietkun profesor Seminarium Duchownego i członek Sądu Biskupiego oceniał proces jako jedno z najważniejszych wydarzeń w stosunkach między Kościołem a systemem marksistowskim. Podważał też wiarygodność zeznań biskupa. Podobnie wypowiadali się również inni księża m.in. Michał Sopoćko ${ }^{10}$. Natomiast odnośnie wydanego 28 września oświadczenia Episkopatu część księży twierdziła słusznie, że zostało ono wydane pod przymusem ${ }^{11}$.

W związku z prowadzoną walką z Kościołem katolickim w marcu 1954 roku KW PZPR w Białymstoku zalecało: stanowcze wyciąganie konsekwencji w stosunku do „reakcyjnej” części księży, wzmocnienie pracy Komisji Duchownych wśród lojalnych i chwiejnych kapłanów oraz zastosowanie represji wobec kurii białostockiej, łącznie ze

9 Szerzej na ten temat: APB, KW PZPR w Białymstoku, Ogólna analiza działalności kurii białostockiej, 10 XII 1953 r., k. 102-105.

10 Urodził się 1 XI 1888 roku w Juszewszczyźnie k. Oszmiany, po ukończeniu szkoły miejskiej był nauczycielem w Zabrzeziu. W latach 1910-1914 przebywał w AWSD w Wilnie. Po święceniach pracował jako wikariusz, w 1918 roku wyjechał do Warszawy i zapisał na Wydział Teologiczny uniwersytetu, zgłosił się na kapelana wojskowego. Od 1922 roku w Wyższym Instytucie Pedagogicznym. Dwa lata później wrócił do Wilna jako proboszcz garnizonowy. W 1926 roku uzyskał doktorat z teologii moralnej na UW, rok później został ojcem duchownym w AWSD. W 1934 roku habilitował się na UW. Podczas pobytu w Wilnie był spowiednikiem zgromadzeń zakonnych, w latach 1933-1936 spowiadał s. Faustynę Kowalską, pod której wpływem rozpoczął szerzenie kultu Miłosierdzia Bożego. W 1944 roku założył Zgromadzenie Sióstr Miłosiernego Zbawiciela. Podczas okupacji pracował w seminarium, udzielał pomocy Żydom. W 1947 roku na wezwanie abp. Jałbrzykowskiego przybył z Wilna do Białegostoku. Zmarł 15 II 1975 roku (M. Sopoćko, Wspomnienia z przeszłości, „Wiadomości Kościelne Archidiecezji w Białymstoku" 1986, nr 1(59), s. 97-121; T. Krahel, Sopoćko Michat [w:] Archidiecezjalne Wyższe Seminarium Duchowne w Białymstoku 1945-1980, Białystok 1981, s. 114-116; H. Ciereszko, Ksiadz Michat Sopoćko, „Czas Miłosierdzia”, I-II 2005 , nr 1, s. 5.

11 APB, KW PZPR w Białymstoku, 33/V/26, Analiza działalności kleru wszystkich szczebli na terenie województwa białostockiego za rok 1953, Białystok 23 I 1954 roku, s. 112 in. 
zdjęciem z urzędu abp. Jałbrzykowskiego. Przyczyną takiego stanowiska bez wątpienia był fakt, że przez cały czas pozostawał wierny swoim zasadom i nie dał się zastraszyć przedstawicielom władz. Dowodziło tego również to, że w lipcu 1954 roku na rekolekcjach alumnów Seminarium Duchownego zakazał nawiązywania kontaktów towarzyskich z osobami skupionymi wokół PAX-u ${ }^{12}$. Potwierdzeniem tego stanu rzeczy było pismo Referatu Organizacji Masowych KW PZPR w Białymstoku do jego odpowiednika w KC PZPR z 30 wrzeHistoria śnia 1954 roku. Stwierdzono w nim m.in., że funkcjonujące tam WSD „od 1945 r. stanowi wybitnie reakcyjne ognisko”, krytykowano Kurię za używanie nazwy „wileńska”, „krzewienie nienawiści do władzy ludowej i ZSRR", szykanowanie księży biorących udział w ruchu postępowym. Ponadto duchowni z kurii i seminarium mówili otwarcie o walce z religią (ks. Pietkun), przytaczano sprawę bp. Kaczmarka i prymasa. Pismo kończyła konkluzja, że ze względu na „stwarzanie trudności w gospodarczym i politycznym budownictwie socjalistycznym" oraz mały zasięg terytorialny (trzy powiaty) należało zlikwidować administrację kurii i seminarium w Białymstoku, placówki parafialne włączyć do Kurii łomżyńskiej, a seminarium oddać pod administrację WSD w Łomży ${ }^{13}$.

Na szczęście dla alumnów, profesorów, jak i całej Kurii plany te nie zostały wprowadzone w życie, co jednak nie oznaczało rezygnacji z prób kontrolowania działalności seminarium. Przykładowo w kwietniu 1955 roku Wydział VI WUds.BP odnotował m.in. wypowiedź rektora WSD w Białymstoku bp. Władysława Suszyńskiego ${ }^{14}$ odnoszącą się do relacji państwo - Kościół. Stwierdził m.in., że duchowieństwo

12 APB, KW PZPR w Białymstoku, 639, Ocena działalności kurii białostockiej za 1954 roku w świetle zawartego porozumienia między rządem a episkopatem, k. 294.

$13 \quad \mathrm{APB}, \mathrm{KW}$ PZPR w Białymstoku, 639, Referat Organizacji Masowych KW PZPR w Białymstoku do KC PZPR Wydział Organizacji Masowych, 30 IX 1954 r., k. 241-243.

14 Urodził się 22 I 1898 roku w Grodnie. Ukończył seminarium w Wilnie, gdzie w 1921 roku przyjął święcenia kapłańskie. Studiował na KUL i Wydziale Filozofii Instytutu Katolickiego w Paryżu, gdzie uzyskał stopień doktora. Profesor WSD w Wilnie, podczas II wojny światowej osadzony przez Niemców w więzieniu na Łukiszkach i w obozie w Szałtupiu. Od 1946 roku rektor i wykładowca Seminarium w Białymstoku. Sakrę biskupią przyjął 9 V 1948 roku. Rektor seminarium, wikariusz generalny i kapitulny (1955-1968) Archidiecezji. 6 VII 1968 roku mianowany administratorem apostolskim polskiej części Archidiecezji Wileńskiej z siedzibą w Białymstoku. Zmarł w Warszawie 27 X 1968 roku. (P. Nitecki, Biskupi kościoła w Polsce w latach 965-1999, Warszawa 2000, s. 424; A. Szot, Konsekracje biskupie w biatostockiejfarze [w:] T. Krahel (red.), Bazylika katedralna $w$ Biatymstoku. Księga jubileuszowa z okazji 100-lecia poświęcenia 
stanowiło przeciwny wobec komunistów obóz ideologiczny oraz wskazał na podejmowane przez władze próby rozbicia jedności Kościoła „od wewnątrz" i dążenie do wprowadzenia w nim niezgody i rozłamu. Skrytykował również księży patriotów jako agentów „,spod sztandaru «Dziś i jutro» oraz «Tygodnika Powszechnego»", głoszących możliwość współistnienia religii z komunizmem. Zapewniał, że działania te nie rozbiją jedności Kościoła. Natomiast jednym z ostatnich aktów sprzeciwu wobec polityki władz komunistycznych ze strony abp. Jałbrzykowskiego była odmowa podpisania w kwietniu tego roku, wspólnie z księżmi: bp. Adamem Sawickim, profesorem seminarium Mieczysławem Paszkiewiczem, Hipolitem Chruścielem, Walentym Urmanowiczem, Michałem Sopoćko i Franciszkiem Wilczewskim Apelu Wiedeńskiej Światowej Rady Pokoju. W miesiącu tym wszczęto też sprawę agenturalnego sprawdzenia kleryka WSD Ryszarda Hermanowicza podejrzanego o ,reprodukcję i rozpowszechnianie wrogich obrazków klerykalnych”. Doniósł o tym informator „Roman”, według którego znalazły się one w posiadaniu kleryków tegoż seminarium. W związku z tym faktem przesłuchano dwóch z nich, jednak nie uzyskano potwierdzenia tych wiadomości. Sam informator wycofał się z wcześniejszego twierdzenia, utrzymywał jednak, że wiedzieli oni o rozpowszechnianiu ich przez Hermanowicza, ale świadkowie nie potwierdzili nawet tego. W związku z powyższym zaczęto wątpić w prawdomówność informatora, postanawiając sprawdzić zarówno kontakt Hermanowicza z fotografem Józefem Kalinowskim, jak też przeszukać pod zmyślonym pretekstem mieszkanie jego matki w Augustowie ${ }^{15}$.

Ostatnia sprawa o kryptonimie „Fotograf” okazała się jednak poważniejsza, a w jej wyniku aresztowano w maju dwu kleryków Seminarium Duchownego w Białymstoku - Ryszarda Hermanowicza i Eugeniusza Tureckiego ${ }^{16}$. W trakcie śledztwa przyznali się oni do wykonania

kościoła Wniebowzięcia Najświętszej Maryi Panny w Białymstoku (1905 - 17 IX - 2005), Białystok 2005, s. 201).

AIPN, 0445/132, Informacja referenta Sekcji I Wydziału VI WUds.BP w Białymstoku dotycząca diecezji białostockiej, 3 V 1955 r., Białystok, k. 95-97; AIPN Bi, 045/1207, Sprawozdanie z pracy Wydziału VI WUds.BP w Białymstoku za kwiecień 1955 r., k. 39.

AIPN Bi, 045/1207, Sprawozdanie z pracy Wydziału VI WUds.BP w Białymstoku za maj 1955 r., k. 45-46; AIPN, 0445/132, Sprawozdanie z pracy Sekcji I Wydziału VI WUds.BP w Białymstoku za maj 1955 r., 1 VI 1955 r., k. 114 (Obrazek przedstawiał u góry MB Częstochowską, niżej św. Andrzeja Bobolę i niewiastę z kajdanami na rękach. Na jednym końcu kajdan była swastyka na drugim sierp i młot. Pod obrazkiem data 1944, leżący sztandar z orłem polskim i napis „Św. A. Bobolo ratuj nas"); AIPN, 0445/132,Sprawozdanie z pracy Wydziału VI WUds.BP w Białymstoku za maj 1955 r., 2 VI 1955 r., k. 141-142. 
reprodukcji obrazka św. Andrzeja Boboli, zaprzeczyli jednak faktowi jego rozpowszechniania. Aparat bezpieczeństwa planował tę sprawę wykorzystać do lepszego rozpoznania stosunków panujących w seminarium. W obronie alumnów wystąpił ks. Witold Pietkun, który napisał list do premiera Cyrankiewicza, tłumaczący odniesienie obrazka do ZSRR i datę niedoświadczeniem i młodym wiekiem ${ }^{17}$. Ubolewał także nad niemożliwością, mimo choroby, odpowiadania z wolnej stopy przez Hermanowicza. List ten trafił także do zaprzyjaźnionych z ks. Kościoła Pietkunem duchownych ${ }^{18}$. 30 listopada1955 roku wyrokiem Sądu Wojewódzkiego w Białymstoku Hermanowicz został skazany na trzy i pół roku więzienia, a Turecki na trzy lata ${ }^{19}$.

Nie zaniechano też inwigilacji duchownych mających wpływ na funkcjonowanie seminarium, jeszcze w maju 1955 r. do sprawy bp. Suszyńskiego aparat bezpieczeństwa uzyskał materiały dotyczące „wrogiego" komentowania przez niego konferencji warszawskiej i ratyfikowania Układu Warszawskiego. Stwierdził on mianowicie, że było to jedynie podanie do publicznej wiadomości istniejącego już od dawna stanu rzeczy. Wskazał, że od początku istnienia tzw. państw Demokracji Ludowej „faktyczną władzę nad siłami zbrojnymi sprawował sztab radziecki”, który miał w dowództwach poszczególnych państw swoich oficerów, którzy nieoficjalnie byli faktycznymi dowódcami sił zbrojnych. W Polsce było to jeszcze bardziej oczywiste ze względu na osobę marszałka Rokossowskiego, który pod „troskliwym okiem Moskwy" kontrolował armię polską. Według biskupa taka sytuacja istniała w każdej dziedzinie funkcjonowania państwa, w każdym ministerstwie ${ }^{20}$.

Na przełomie 1955 i 1956 roku podjęto działania zmierzające do usunięcia $\mathrm{z}$ dotychczas zajmowanych stanowisk ks. Pietkuna, profesora seminarium duchownego w Białymstoku, i ks. Abramowicza ${ }^{21}$. W przypadku pierwszego z nich pismo do Kurii białostockiej wystosował przewodniczący Prezydium WRN Józef Szcześniak, który powołując

17 AIPN Bi, 030/465, Ks. W. Pietkun do Premiera J. Cyrankiewicza, 2 XI 1955 r., k. 32-33.

18 AIPN Bi, 087/233/2, Meldunek sytuacyjny do naczelnika Wydziału I Departamentu VI Komitetu do Spraw Bezpieczeństwa Publicznego w Warszawie, 15 XII 1955 r., k. 96.

19 AIPN, 1583/170, Analiza sytuacji operacyjnej woj. białostockiego za rok 1955, 30 I 1956 r., k. 14. za maj 1955 r., 2 VI 1955 r., k. 145.

21 AIPN, 1583/170, Analiza sytuacji operacyjnej woj. białostockiego za rok 1955, 30 I 1956 r., k. 14-15. 
się na dekret z 9 lutego 1953 roku, prosił o poinformowanie o podjętych wobec duchownego działaniach ${ }^{22}$. W sprawie tej Kuria interweniowała u dyrektora Urzędu do Spraw Wyznań Mariana Zygmanowskiego w Warszawie ${ }^{23}$. Przypomniano, że zgodnie ze wspomnianym dekretem najpierw powinno się ostrzec księdza za pośrednictwem organów kościelnych, a następnie przedstawione mu określone zarzuty, z których miał się poprawić. Ostatnim dopiero elementem było żądanie usunięcia, w związku z czym proszono o jego uchylenie. Niestety otrzymana 7 marca 1956 roku odpowiedź utrzymywała decyzję PWRN w Białymstoku w mocy i nie odnosiła się do przedstawionej argumentacji ${ }^{24}$. Skutkiem tego było odwołanie się przez Kurię do Prezesa Rady Ministrów Józefa Cyrankiewicza ${ }^{25}$.

Przez następne lata również gromadzono materiały dotyczące wypowiedzi poszczególnych duchownych związanych z seminarium. Przykładowo w związku z przypadającym 14 września 1958 r. świętem kościelnym „podniesienie krzyża”, zainteresowano się wystąpieniami mającymi miejsce podczas nabożeństw w kościołach rzymskokatolickich na terenie województwa białostockiego. W trakcie jednego z nich na odpuście w Olecku kazanie wygłosił ks. Stanisław Bielawski, prof. WSD z Białegostoku. Początkowo oceniono je jako „utrzymane w tonie umiarkowanym, obracające się wokół zagadnień religijnych". Według aparatu bezpieczeństwa dalsza jego część nosiła jednak cechy protestu przeciwko działaniom rządu wobec Kościoła. Duchowny odniósł się m.in. do wydarzeń polskiego października, które określił jako ,wielki akt odrodzenia narodowego, wielki przełom w życiu narodu”. Posłużył się przy tym przykładem z wypadków w Białymstoku po VIII Plenum, kiedy tłum manifestantów ze sztandarem wkroczył do kościoła św. Rocha po przejściu trasy od kościoła Farnego. Według niego jednak październik trwał bardzo krótko, a po okresie odprężenia i pełnej swobody również w zakresie wiary pojawiły się ponownie zjawiska niepokojące ,świadczące o tym, że komuś w Polsce wiara katolicka była nie potrzebna, że ktoś chce ją wytrzebić z ludzkich serc". Zdaniem duchownego nie nastąpi to nigdy, czego przykładem

22

AIPN Bi, 030/465, Józef Szcześniak przewodniczący PWRN w Białymstoku do kurii białostockiej, 1 II 1956 r., k. 21.

Ibidem, Ks. A. Sawicki do ministra M. Zygmanowskiego dyrektora Urzędu do Spraw Wyznań w Warszawie, 10 II 1956 r., k. 22-23.

24

Ibidem, Urząd do Spraw Wyznań do kurii diecezjalnej w Białymstoku, 7 III 1956 r., k. 24.

25 AIPN Bi, 030/465, Kuria arcybiskupia w Białymstoku do Prezesa Rady Ministrów J. Cyrankiewicza, 6 IV 1956 r., k. 25-26. 
byli pierwsi chrześcijanie, którzy przetrwali prześladowania w Cesarstwie Rzymskim. Ksiądz Bielawski wskazał, że naród polski w 95\% był katolicki, a ponadto po październiku 1956 roku rząd oświadczył, że robotniczą Łódź i Śląsk zamieszkiwały „masy robotnicze praktykujące religię". W takim wypadku wydanie walki religii oznaczałoby walkę z klasą robotniczą, która była fundamentem państwa i nikt nie chciał z nią konfliktu. Zdaniem duchownego, niestety po okresie, kiedy naród wyzwolił w pełni swoje uczucia religijne (nawet członkowie Historia partii zaczęli chodzić do kościoła), nastąpił powrót do starych metod. Jedną z nich była kontynuacja nagonki na księży, których starano się „zohydzić” w oczach wiernych. Przytoczył też przy tym powiedzenie „Chcesz rozpędzić owieczki - uderz w pasterza”. Na zakończenie ks. Bielawski powiedział, że uroczystości Podniesienia Krzyża Świętego posiadały wielkie znaczenie, gdyż był on symbolem odkupienia ludzkości, zwycięstwa i pracy. Z tego względu nie da się go wykreślić z życia, nie pomogą pod tym względem żadne posunięcia oraz zawsze będzie „drogowskazem w życiu katolika jako znak zbawienia i wiecznego triumfu" ${ }^{26}$.

Natomiast 29 października 1959 roku SB KW MO w Białymstoku uzyskała materiały wydane przez Episkopat do wszystkich diecezji w kraju, w którym informowano ordynariuszy o sposobie postępowania w razie próby objęcia przez władze nadzoru nad seminariami, które miało nastąpić zgodnie z pismem ${ }^{27}$ Prezesa Rady Ministrów do Episkopatu 12 października. Zalecano w nim poinformowanie rektorów, iż nie powinni przekazywać żadnych informacji i dokumentów oświadczając, że sprawa była rozpatrywana na wyższym szczeblu ${ }^{28}$.

Relacji z władzami nie poprawiło też z pewnością zarządzenie ministra oświaty z 29 grudnia 1959 roku, wprowadzające nadzór państwowy nad Seminariami Duchownymi ${ }^{29}$. Sprawa ta powracała w relacjach władze - Kościół od początku 1960 roku, już 11 stycznia poruszona została w trakcie rozmowy kard. Wyszyńskiego z Władysławem

$26 \quad$ AIPN, 0445/133, Meldunek specjalny do dyrektora Gabinetu Ministra MSW w Warszawie dotyczący przebiegu uroczystości kościelnych „podniesienia krzyża", 16 IX 1958 r. Białystok, k. 482-483.

27 Szerzej zob. A. Dudek, Państwo i Kościót w Polsce 1945-1970, Kraków 1995, s. 126.

28 AIPN, 0445/133, Informacja zastępcy KW MO ds. B w Białymstoku do wicedyrektora Gabinetu Ministra MSW w Warszawie o uzyskanych materiałach po zagadnieniu kleru katolickiego, 29 X 1959 r., k. 172-173.

29 A. Dudek, I. Marczak, Wstęp [w:]Uroczystości milenijne 1966 roku. Sprawozdania urzędów spraw wewnętrznych, Warszawa 1996, s. 8. 
Gomułką, nie przyniosło to jednak żadnego rezultatu ${ }^{30}$. W efekcie 25 marca 1960 roku prymas w liście do I sekretarza KC PZPR protestował przeciwko usiłowaniom wprowadzenia nadzoru Ministerstwa Oświaty nad Seminariami Duchownymi bez konsultacji z Episkopatem oraz Komisją Wspólną. Dodatkowo podporządkowanie WSD Kuratorium dla Szkół Średnich i Podstawowych uważane było za próbę upokorzenia Kościoła ${ }^{31}$. W województwie białostockim sytuację w Seminariach Duchownych analizował aparat bezpieczeństwa, podkreślający mniejszy nabór na I kurs, jak sugerowano, spowodowany rejestracja wojskową alumnów i pogłoską o zamiarze powoływania ich do wojska. Jak wynikało z rozpoznania prowadzonego przez aparat bezpieczeństwa wielu kleryków (szczególnie z młodszych kursów) wykazywało chęć pójścia do wojska, widząc w tym najdogodniejszą i usprawiedliwiającą ich sytuacje do porzucenia stanu duchownego. Inni byli zdania, że każdy ksiądz winien przejść przeszkolenie wojskowe po to, aby lepiej poznać różne dziedziny życia społecznego. Uważali, że byłby to najlepszy sprawdzian powołań kapłańskich (ci, którzy wrócą do seminarium po odbytej służbie wojskowej udokumentują swoje powołanie). Gdy jednak okazało się, że do wojska powołano jedynie kleryków z WSD w Kielcach, w seminarium w Białymstoku zaczęto przypuszczać, że była to jedynie próba zastraszenia przez władze państwowe w celu powstrzymania naboru kandydatów na I kurs. Ksiądz prof. Józef Czerniawski zastanawiając się nad przyczyną niskiego naboru kandydatów do seminariów doszedł do wniosku, iż głównym powodem było poważne zeświecczenie młodzieży i szerokie możliwości dostania się na kierunki studiów świeckich. Według niego, władze komunistyczne „bardzo ostro” zajęły się walką z Kościołem katolickim w Polsce, szczególnie zaś nakładaniem podatków, pogarszających warunki bytowe kleryków w seminariach i księży na parafiach. W WSD w Białymstoku przyjmowano przeciętnie dziewiętnaście osób, a w roku szkolnym 1959-1960 tylko siedem, z czego dwie zrezygnowały z kontynuacji nauki, ponadto (według SB) dalsze 13 usunięto z seminarium za „niesubordynację wobec zarządzeń w kwestii dyscypliny, wolnomyślicielstwo oraz z braku powołania". Ilość zwolnionych stanowiła największy odsetek, nienotowany dotychczas w tym seminarium. Aparat bezpieczeństwa odnotował również, iż w okresie ferii zimowych klerycy VI kursu WSD indywidualnie poszli na przedstawienie opery

\footnotetext{
$30 \quad$ A. Dudek, Państwo i Kościót w..., op. cit., s. 127.

31 Kardynał S. Wyszyński do I Sekretarza KC PZPR W. Gomułki, 25 III 1960 r. Warszawa [w:] S. Bogdanowicz Kościót gdański pod rządami komunizmu 19451984, Gdańsk 2000, s. 130.
} 
Halka Warszawskiego Teatru Objazdowego. O fakcie tym dowiedziały się władze seminaryjne, które dwóm klerykom wstrzymały wyższe święcenia kapłańskie (diakonaty), a pozostałym (którzy już je mieli) zwrócono uwagę za wyłamywanie się z zasad regulaminu seminaryjnego. Wypadek ten spowodował wstrzymanie wyświetlania filmów w seminarium (naukowych, dokumentalnych i bajek), a kanclerz Kurii ks. Piotr Maziewski wydał zarządzenie zabraniające księżom uczęszczania do kin i na inne imprezy rozrywkowe w obrębie diecezji ${ }^{32}$.

Pewien niepokój wśród kleryków WSD w Białymstoku wywołała także sprawa opłaty za pobyt w seminarium. Do końca 1959 roku było to 150 zł miesięcznie, suma ta została jednak zwiększona do 450 zł. Podwyżkę uzasadniono wzrostem cen żywności oraz nałożeniem przez państwo dodatkowych podatków na WSD. Sprawą wyżywienia alumnów zainteresował się bp Suszyński, co doprowadziło do konfliktu między nim, a prokuratorem seminarium ks. Maciejem Pawlikiem. W wyniku tego, ten drugi zrzekł się pobierania od alumnów pieniędzy, a zadanie to powierzono dwuosobowej komisji społecznej, która zebrane od alumnów pieniądze miała przekazywać bezpośrednio szefowej kuchni za pokwitowaniem.

Dużym zaskoczeniem wywołującym niepokój była też wiadomość o przejęciu przez państwo nadzoru nad seminariami duchownymi. W związku z tym wydarzeniem sekretarz Episkopatu pismem nr 100 z dnia 15 lutego 1960 roku zażądał od ordynariuszy Kurii niezwłocznego nadesłania informacji, która miała zawierać odpowiedzi na następujące punkty: czy rektor był wzywany do kuratorium, powiadomiony o składzie komisji oraz o terminie? Kto wchodził w skład komisji? Czym komisje się interesowały, jakie stawiano pytania? Czy komisja interesowała się gmachem seminaryjnym? Już 6 kwietnia 1960 roku Kuratorium Okręgu Szkolnego w Białymstoku poinformowało bp. Suszyńskiego o planowanej wizytacji. Początkowo Biskup nie chciał wyrazić zgody na tego rodzaju wizytacje, gdyż jak tłumaczył, zabraniało mu tego prawo kanoniczne, potrzebował również zezwolenia ordynariusza. Po dłuższej rozmowie zgodził się jednak na dokonanie wizytacji seminarium 7 kwietnia 1960 roku i na ogólne zapoznanie przedstawicieli kuratorium z warunkami lokalowymi. Uczestniczyli w niej ze strony kościelnej rektor, wicerektor ks. Cichoński, później też ordynariusz diecezji ks. Adam Sawicki. Zanim się jednak wizytacja rozpoczęła bp Suszyński ponownie zaprotestował przeciwko takim

32 AIPN, 0445/133, Informacja zastępcy KW MO ds. SB w Białymstoku ppłk K. Modelewskiego do wicedyrektora Gabinetu Ministra MSW w Warszawie o sytuacji w seminariach duchownych na terenie woj. białostockiego, 11 V 1960 r., k. 265-270. 
działaniom, wskazując m.in. na toczące się rozmowy między rządem a Episkopatem i brak instrukcji w tej sprawie. Starał się również udowodnić, że art. 5 tego porozumienia mówił o jurysdykcji papieża, a wszelkie poczynania władz były mieszaniem się w wewnętrzne sprawy Kościoła. W związku z wyżej wymienionymi argumentami odmówił udzielenia jakichkolwiek informacji, chyba że na piśmie, na polecenie Wydziału ds. Wyznań. Jednak w czasie dalszej rozmowy bp Suszyński nie przedstawiając dokumentów częściowo poinformował o ilości alumnów, składzie profesorskim, programie zajęć i o pracy wychowawczej. Zdaniem rektora WSD w Białymstoku zarządzenie o sprawowaniu nadzoru nad Seminariami Duchownymi przez państwo było wydane w celu ,przyduszenia” duchownych i stanowiło ingerencję w wewnętrzne sprawy seminariów, pozbawioną wszelkich podstaw prawnych. Według niego, seminarium było szkoła prywatna, nieotrzymującą od państwa żadnych dotacji, więc niepodlegającą jego kontroli ${ }^{33}$.

Natomiast 29 kwietnia 1960 roku SB KW MO w Białymstoku informowała wicedyrektora Gabinetu Ministra MSW w Warszawie, iż nieoficjalnie otrzymała informację o planach przeniesienia przez Kurię w Białymstoku WSD z dotychczasowej siedziby przy ul. Słonimskiej do nowo wybudowanego budynku przy ul. Traugutta. W toku prowadzonych działań ustalono, że dotychczasowe pomieszczenia były własnością Kuratorium Okręgu Szkolnego w Białymstoku, które nie przedłużyło dzierżawy wygasającej właśnie w tym roku. Poszukując nowych pomieszczeń Kuria w 1958 roku uzyskała w Prezydium MRN w Białymstoku zezwolenie na rozpoczęcie budowy przy byłym kościele garnizonowym. Poinformowała ona przy tym władze, że budynek będzie przeznaczony na mieszkania dla kleryków, co z pewnością wzięto pod uwage przy wydaniu zezwolenia. Według SB w tym przypadku jednak złamano istniejące przepisy Urzędu ds. Wyznań, według których takie zezwolenie wydać powinno (jak też prowadzić nadzór nad budową) Prezydium WRN i jego Wydział ds. Wyznań. Sprawy tej nie uzgodniono z MON, które było prawowitym właścicielem terenów po byłych koszarach. Ponadto planowany budynek, mający być początkowo parterowym, bez zezwolenia rozbudowano z przeznaczeniem na seminarium. O fakcie tym 27 kwietnia aparat bezpieczeństwa poinformował przewodniczącego PWRN i kierownika Wydziału ds. Wyznań, mających wstrzymać wspomnianą budowę i wyciągnąć konsekwencje

$33 \quad$ Ibidem. 
w stosunku do pracowników PMRN odpowiedzialnych za wydanie zezwolenia $^{34}$.

Elementem prowadzonej walki było też poinformowanie na początku lat sześćdziesiątych przez będące wówczas właścicielem budynku, w którym mieściło się seminarium Kuratorium Okręgu Szkolnego o kończącym się terminie umowy najmu. 19 lipca 1961 roku odbyła się rozprawa przed Sądem Powiatowym w Białymstoku, podczas której interesów WSD bronił adwokat Ellert, próbujący doprowadzić do rozpatrywania sprawy przez Sąd Wojewódzki. W związku ze zgłaszanymi przez obronę wnioskami ogłoszenie wyroku odłożono do 26 lipca. Ostatecznie Sąd Powiatowy wydał wyrok nakazujący przeniesienie seminarium z ul. Słonimskiej na ul. Orzeszkową 5. Decyzję tę strona kościelna interpretowała jako swoisty odwet za uniemożliwienie przeprowadzenia ostatniej z wizytacji. Trzy dni później PMRN wystosowało „zarządzenie egzekucyjne”, pomimo tego, że nowa siedziba nie była w pełni przygotowana na przyjęcie alumnów ${ }^{35}$.

Opróżniony z alumnów budynek został przekazany przez Kuratorium Okręgu Szkolnego w Białymstoku na rzecz Domu Młodzieży nr 2. Pomimo nacisków władz do 22 sierpnia 1961 roku przeprowadzka seminarium nie została jeszcze całkowicie zakończona, ze względu na zajmowanie mieszkania przez prokuratora WSD ks. Macieja Pawlika i pozostawione wyposażenie kaplicy. Z tego powodu przewodniczący PWRN przeprowadził rozmowę z ks. Adamem Sawickim, podczas której ordynariusz Kurii białostockiej zobowiązał się dokończyć obie sprawy w ciągu tygodnia. Analizujący całą sytuację aparat bezpieczeństwa jako najaktywniejszego przeciwnika przenosin wskazał właśnie ks. Pawlika, który w ich trakcie podczas rozmów z pracownikami MRN sugerował, iż była to próba likwidacji seminarium. Jego działalności (,wytwarzanie podatnego gruntu do uaktywnienia się fanatyków religijnych") przypisano też zebranie się 16 sierpnia przed budynkiem przy ul. Słonimskiej około 30 kobiet. Zgromadziły się one w związku z pogłoskami o przenosinach kaplicy, jedna z nich położyła pod drzwiami bukiet kwiatów, a wszystkie rozeszły się z chwilą

$34 \quad$ AIPN, 0445/133, Informacja zastępcy komendanta KW MO ds. Bezpieczeństwa w Białymstoku do wice dyrektora Gabinetu Ministra MSW w Warszawie, 29 IV 1960 r. Białystok, k. 255-256.

35 AIPN, 045/623, Informacja zastępcy KW MO ds. Bezpieczeństwa w Białymstoku ppłk. L. Sobczyka do wicedyrektora gabinetu ministra MSW w Warszawie, 27 VII 1961 r. Białystok, k. 49-50; T. Krahel, Dzieje Archidiecezjalnego Wyższego Seminarium Duchownego..., op. cit., s. 32. 
wysłania tam patroli milicji ${ }^{36}$. Ostateczne opuszczenie pomieszczeń byłego seminarium (przewiezienie przedmiotów z kaplicy do kościoła św. Wojciecha), kontrolowane przez aparat bezpieczeństwa, nastąpiło w dniach 4-6 września 1961 roku. Wcześniej zajmowane mieszkanie opuścił ks. Pawlik, co nie pociągnęło za sobą żadnych konfliktów. Skutkiem przeprowadzki WSD była natomiast pogłoska o planowanym połączeniu seminarium z jego odpowiednikiem w Łomży ${ }^{37}$.

Wymuszona zmiana siedziby nie oznaczała końca walki władz komunistycznych z seminarium i szerzej z Kościołem rzymskokatolickim. Również w następnych latach poszukiwano sposobów ograniczenia jego działalności, czego przykładem był telefonogram Urzędu do Spraw Wyznań w Warszawie wysłany do Wds.W PWRN w Białymstoku 29 czerwca 1965 roku. Mianowicie w piśmie tym zasygnalizowano możliwość ewentualnego wyciągnięcia konsekwencji w stosunku do Wyższego Seminarium Duchownego, ze względu na jego „,zdecydowanie negatywną postawę wobec władz i obowiązujących przepisów państwowych". Odnosząc się do niego ponownie dokonano analizy materiałów dotyczących powstania i funkcjonowania WSD wskazując, iż chociaż sięgało do tradycji seminarium w Wilnie, to w Białymstoku ukształtowało się dopiero w czasie powojennym. Od tej pory kształciło duchownych dla potrzeb diecezji białostockiej i każdego roku liczyło przeciętnie około 40 alumnów. Wraz z upływem czasu liczba ta poważnie zmniejszyła się i w 1965 roku wynosiła 23 alumnów (na I kursie siedmiu, na II pięciu, na III dwóch, na IV dwóch, na V trzech i na VI czterech). Nie pominięto spraw lokalowych przypominając, że w początkowym okresie seminarium mieściło się przy ul. Słonimskiej, a w 1961 roku po wygaśnięciu umowy najmu przeniesione zostało do budynku stanowiącego uprzednio własność Towarzystwa „Pomoc” przy ul. Orzeszkowej 5. Od tego czasu wykorzystywało też jako salę wykładową budynek przy ul. Warszawskiej 46, o który toczył się spór z Kościołem ewangelicko-augsburskim. Poziom nauczania oceniono jako lepszy niż w seminarium w Drohiczynie, lecz trochę słabszy niż w łomżyńskim. Jako ,negatywnie ustosunkowany do państwowych przepisów i zarządzeń" wskazano osobę rektora bp Władysława Suszyńskiego, który „wpajał alumnom oraz realizował wszystkie zalecenia episkopatu", m.in. od 1964 roku uniemożliwiał przeprowadzenie

$36 \quad$ AIPN, 045/623, Informacja zastępcy KW MO ds. Bezpieczeństwa w Białymstoku ppłk.K. Modelewskiego do wicedyrektora gabinetu ministra MSW w Warszawie, 22 VIII 1961 r. Białystok, k. 83-84.

37 AIPN, 045/623, Informacja zastępcy KW MO ds. Bezpieczeństwa w Białymstoku ppłk. K. Modelewskiego o zakończeniu eksmisji WSD, 8 IX 1961 r. Białystok, k. 126. 
wizytacji seminarium. Podobnie oceniono wicerektora ks. Cichońskiego. Prefektem seminarium został ks. Stanisław Piotrowski, będący jednocześnie profesorem i „szerzący katolicyzm wśród studentów i inteligencji". Pozostała kadra profesorów pozostawała pod ich wpływem, szczególnie bp. Suszyńskiego uznawanego za „najbardziej reakcyjnego" na terenie diecezji.

Ponadto w okresie tym na WSD ciążyły nadal zadłużenia finansowe: 264 tys. zł podatku dochodowego do 1963 roku, 77 tys. podatku od nieruchomości za wcześniejsze lata, $25 \%$ odsetek za zwłokę od wspomnianych kwot i podatek dochodowy za 1964 roku w granicach około 73 tys. zł. Odpowiadając na pismo Uds.W wskazano jednak, że stosowanie wobec WSD daleko idących sankcji jak likwidacja byłoby niewskazane, gdyż uderzyłoby bezpośrednio w administratora diecezji ks. bp Sawickiego, który mimo „wielu bardzo negatywnych pociągnięć, nie prowadzi jednak walki na płaszczyźnie administracyjnej”. Realizując daleko idące wnioski proponowano wcielić do wojska co najmniej sześciu alumnów WSD w Białymstoku mających kategorię „A" i podlegających powołaniu (na komisję stanęło trzynastu alumnów, z czego siedmiu otrzymało tę kategorię). Gdyby to okazało się niemożliwe do realizacji proponowano dokonać kontroli biblioteki WSD i skonfiskować wszystkie pozycje znajdujące się na indeksie. W dalszej kolejności do wojska mieli być wcieleni wszyscy alumni przyjęci do seminarium w $1965 \mathrm{roku}^{38}$.

Wyższe Seminarium Duchowne w Białymstoku rozpoczynało swą działalność w niezwykle trudnych warunkach. Wyrzucone ze swoich budynków, zmuszone do opuszczenia razem z duchownymi Wilna, znalazło przystań w zniszczonym i niemającym takiego znaczenia Białymstoku. Nowa Polska, ze względu na panoszących się w niej komunistów, nie okazała się też tą, którą znali sprzed 1939 roku. Prowadzona przez utrwalany przy wsparciu sowietów system, walka z Kościołem rzymskokatolickim nie ominęła również WSD, a celem ataku stali się alumni, jak i profesorowie. Szczególnie uwidoczniło się to w pierwszej połowie lat pięćdziesiątych, kiedy miały miejsce najbardziej restrykcyjne działania, włącznie z planami likwidacji seminarium. Wbrew oczekiwaniom także okres po chwilowej odwilży 1956 roku nie przyniósł tak upragnionego spokoju, a WSD wraz z duchowieństwem białostockim pozostało obiektem działań prowadzonych przez władze administracyjne i aparat bezpieczeństwa.

38 AIPN, 0445/133, Informacja PWRN w Białymstoku Wds.W do dyrektora Uds.W w Warszawie, 30 VI 1965 r., k. 616-621. 
Słowa klucze: Kościół katolicki, Służba Bezpieczeństwa, Wyższe Seminarium Duchowne, Rada Narodowa.

\section{Bibliografia:}

1. Bogdanowicz S., Kościót gdański pod rzq̨dami komunizmu 1945-1984, Gdańsk 2000.

2. Dudek A., Marczak I., Wstęp [w:] Uroczystości milenijne 1966 roku. Sprawozdania urzędów spraw wewnętrznych, Warszawa 1996.

3. H. Ciereszko, Ksiadz Michat Sopoćko, „Czas Miłosierdzia”, I-II 2005, nr 1.

4. Krahel T., Dzieje Archidiecezjalnego Wyższego Seminarium Duchownego $w$ Biatymstoku [w:] Archidiecezjalne Wyższe Seminarium Duchowne w Biatymstoku 1945-1980, opr. E. Ozorowski, Białystok 1981.

5. Krahel T., Seminarium duchowne $w$ Biatymstoku $w$ minionym50-leciu, „Wiadomości Kościelne Archidiecezji Białostockiej” 1995, nr 4(99).

6. Krahel T., Sopoćko Michat [w:] Archidiecezjalne Wyższe Seminarium Duchowne $w$ Biatymstoku 1945-1980, Białystok 1981.

7. Nitecki P., Biskupi kościoła w Polsce w latach 965-1999, Warszawa 2000.

8. Sopoćko M., Wspomnienia z przeszłości, „Wiadomości kościelne Archidiecezji w Białymstoku" 1986, nr 1(59).

9. Sychowicz K., Wtadze komunistyczne wobec Kościotów i zwiazków wyznaniowych w województwie białostockim w latach 1944-1945, Białystok 2013. 10. Szot A., Abp Romuald Jatbrzykowski metropolita wileński, Lublin 2002.

11. Szot A., Konsekracje biskupie w biatostockiej farze [w:] T. Krahel (red.), Bazylika katedralna w Biatymstoku. Księga jubileuszowa z okazji 100-lecia poświęcenia kościoła Wniebowzięcia Najświętszej Maryi Panny w Białymstoku (1905 - 17 IX - 2005), Białystok 2005. 